\title{
Blended learning motivation model for instructors in higher education institutions
}

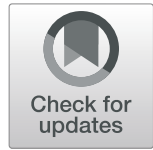

\author{
Mohammed Mansur Ibrahim *id and Muesser Nat
}

\author{
* Correspondence: \\ 20143383@student.ciu.edu.tr \\ Management Information Systems \\ Department, Cyprus International \\ University, via Mersin 10, \\ Haspolat-lefkosa, Turkey
}

\begin{abstract}
Currently, blended learning (BL) is trending among higher education institutions (HEls) around the globe. Despite its popularity, no model exists that describes the motivation that affects instructors' opinions and beliefs regarding online learning. Therefore, the purpose of this study is to identify the factors responsible for motivating instructors at HEls to integrate the BL approach into their courses. Two categories of motivational factors, namely, extrinsic and intrinsic, have been identified in the BL literature. These factors have been used to design a motivation model based on the cause-effect relationship between them. Survey data were collected from $362 \mathrm{HEl}$ instructors in Turkey and North Cyprus for analysis using a structural equation modelling method. The results indicated that both extrinsic and intrinsic motivational factors have a significant impact on the instructors' motivation to apply the BL approach. However, the extrinsic factor, i.e., "academic workload", did not influence the instructors' motivation. In general, the findings confirmed that, the consideration of both extrinsic and intrinsic factors for motivating the application of blended learning has a $79 \%$ impact on the adoption of BL. The findings of this study provide practical solutions for educational managers, curriculum designers and faculty members towards creating a cohesive BL environment in HEls.
\end{abstract}

Keywords: Blended learning, Higher education institutions, Instructor, Motivation model, Structural equation model

\section{Introduction}

The current trend of technology utilization in our daily routine lives has brought about changes with regard to knowledge distribution, construction and reconstruction (Lim \& Wang, 2016). The widespread availability of information and communication technologies (ICT) has also transformed higher education institutions (HEIs) into multi-choice learning environments that complement classroom learning experience and increase learning based on individual preference, which is independent of time and place (Singh \& Kaurt, 2016). However, there is a desire to transform teaching and learning from a teacher-centred model to a learner-centred model through instructor empowerment with ICT integration in all aspects of teaching and learning (Jani, Muszali, Nathan, \& Abdullah, 2018). Recently, HEIs have experienced a shift in perception from fully online distance learning towards BL as an enhancement of face-to-face teaching methods (Johnson et al., 2016).

(c) The Author(s). 2019 Open Access This article is distributed under the terms of the Creative Commons Attribution 4.0 International License (http://creativecommons.org/licenses/by/4.0/), which permits unrestricted use, distribution, and reproduction in any medium, provided you give appropriate credit to the original author(s) and the source, provide a link to the Creative Commons license, and indicate if changes were made. 
Blended learning is an effective approach to the passive knowledge engagement of a massive number of students, which also increases learning outside the traditional face-to-face learning environment (Oakley, 2016). Additionally, BL is currently trending among institutions due to its positive impact on student motivation and performance in general, as indicated by Lu et al. (2018). BL helps instructors engage students in active learning that promotes skills such as communication, information literacy, creativity and collaboration that transform into the ability to use digital technologies for different purposes. If adopted appropriately, then BL can turn HEIs into a more flexible and agile state to quickly adapt to contextual changes; in a cost-effective manner (Oakley, 2016). Although BL has tremendous benefits for academics, there are also certain drawbacks concerning its implementation, for instance, the absence of an institutional vision shared with the front-line teaching staff. There may be a gap in the area of capacity building for BL together with the expected level of engagement for the teaching staff. The lack of adequate institutional support for BL may also decrease the motivation of the instructors to transform their courses into the blended format that can discourage their commitment to change (Lim \& Wang, 2016). Furthermore, the BL approach offers numerous advantages to instructors, but negative perceptions held by these instructors may affect its application according to Tshabala, Ndeya-Ndereya, and van der Merwe (2014).

Additionally, there is a call for further research on different BL models with regard to experimental research to test the design principles for blended online learning and principles for face-to-face instruction for different kinds of learners (Means, Toyama, Murphy, \& Baki, 2013). In another effort, to investigate the increasing instructor interaction and the levels of learning through active research in a blended course, Çardak and Selvi (2016) reported the absence of a significant and effective BL process regarding the instructor's interaction with the learning levels of students. Moreover, a call was also made for more experience in blended and online learning environments that could provide opportunities for graduate students or future instructors to shift their attitudes regarding online learning (Sheffield, McSweeney, \& Panych, 2015). Similarly, Rolfe and Gray (2011) suggested the evaluation of the effectiveness of self-directed studies that are aided with distance learning resources appropriate for modern educational models. The literature also shows that, the implementation of BL is more successful with instructor motivation in the classroom, but unfortunately, there is a lack of adequate research on instructor motivation with regard to integrating educational technology in the classroom (Schechter, Kazakoff, Bundschuh, Prescott, \& Macaruso, 2017). While online instructional technologies are becoming more popular in HEIs, the instructor's opinions and beliefs regarding online learning tend to be generally negative (Patchan, Schunn, Sieg, \& McLaughlin, 2016). Moreover, despite faculty's significant role in the success of a university's BL implementation efforts, "little has been published regarding faculty application of hybrid teaching” (Porter, Graham, Bodily, \& Sandberg, 2016, p.17). To realize the potential of $\mathrm{BL}$, there is a need for more investigations on academic development to better understand the instructors' concerns regarding BL practices Torrisi-Steele and Drew (2013). To facilitate BL in academic institutions, there is an absolute need for the school to have a clear and supportive institutional policy, leadership and practice related to their BL courses (Johnson et al., 2016). Previous research on technology application often focuses on barriers and concerns regarding utilizing 
technology in the classroom, according to Nicolle and Lou (2008), and there is a glaring absence of a model to evaluate the effectiveness of blended e-learning by many higher institutions (Aguti, Wills, \& Walters, 2014). Additionally, much of the existing research on BL; often focuses on its pedagogical benefits, which often project faculty to be less in the picture of BL research, according to Benson and Kolsaker (2015). All of these factors necessitate the shift of our focus to the instructors because students are always the case. Therefore, this study intends to address the problem of the minimal research focus on instructors in the field of BL, with a goal of supporting their motivation through a model design and evaluating the model in the context of a higher education institution.

This paper is organized as follows. The first section after the introduction presents a BL theoretical background with a theoretical model and hypotheses. Section two describes the methodology adopted by the study, and section three presents the results obtained from structural equation modelling. Section four discusses the findings and their significance, and section five concludes the paper together with research limitations and future studies.

\section{Theoretical background \\ Blended learning}

Although there are several definitions of $\mathrm{BL}$, it is an instructional model that combines different forms of media such as text, audio and video at different time scales (synchronous, asynchronous) with the face-to-face method of instruction within the same course (Roseth, Akcaoglu, \& Zellner, 2013). BL combines face-to-face learning with an online learning style, where $30-79 \%$ of the content is delivered online. This model is also referred to as a blended pedagogical method or a blend of didactic methods and delivery styles (Al-Busaidi, 2013). Alternatively, BL can be viewed as the combination of an online teaching method with face-to-face instruction (Ramirez-Arellano, Bory-Reyes, \& Hernández-Simón, 2018). Driscoll (2002, p.1) defines BL by categorizing the concept into four different groups: "to combine or mix modes of web-based technology (e.g., live virtual classroom, self-paced instruction, collaborative learning, streaming video, audio, and text) to accomplish an educational goal; to combine various pedagogical approaches (e.g., constructivism, behaviourism, cognitivism) to produce an optimal learning outcome with or without instructional technology; to combine any form of instructional technology (e.g., videotape, CD-ROM, web-based training, film) with face-to-face instructor-led training; and to create mixing or actual training or mixing of technology to create harmful tasks and work tasks. Scholars have unanimously agreed on BL as a form of pedagogy that combines the face-to-face learning method and online instruction with a certain number of issues remaining in contention. These issues include what to be blend, whether to add a reduction of seat hours in the definition or be specific regarding the amount of time for both online and face-to-face instruction or to solve the problem of pedagogical quality in the definition (Bocconi \& Trentin, 2014; Porter et al., 2016). Porter, Graham, Spring, and Welch (2014) stressed the fact that institutions of higher education are adopting blended learning in high numbers and referred to $\mathrm{BL}$ as the combination of technology-supported learning and face-to-face learning methods. Moreover, the editor of the journal of synchronous 
learning networks forecasted that $80-90 \%$ of higher education courses would become blended in the future, and at the time of this statement, scholars have started to note the "explosive growth of blended learning" and have mentioned that BL will become the "new normal" way of learning in higher education (Porter et al., 2014, p.185).

\section{Factors responsible for motivating instructors to adopt blended learning}

In this sub-section, the major causes of the application of BL among instructors of HEIs are reviewed. Lu et al. (2012) indicated that factors responsible for motivating instructors to accept BL consist of interest, independent learning, personalized learning, computer self-efficacy, social perception, external expectation and improvement of skills. The study also discovered other influential factors grouped into two categories, extrinsic and intrinsic, based on individual faculty members' experience in BL practices (Brown, 2016). Intrinsic influences have its catalyst as the individual cognition of the instructor. An excellent example of such is the faculty member's instructional philosophy which is most noticeable in many studies. Additionally, the instructional model used by the instructors are mental models (Hora, 2012). Although from reflection and experience, faculty have developed a mental model of practice that indicates how to carry out instructions (Cochran-Smith \& Lytle, 1999). Depending on the researcher's analytic interest, external influences can be termed cultural, structural or instructional factors. Another investigation by Torrisi-Steele and Drew (2013) viewed the instructor's motivation for impacting BL applications as follows: perceptions of usefulness, professional support, the point of need for technical support, funding, preparation time, institutional infrastructure, the involvement of senior staff, and efficacy, these factors are important variables of the technology application among instructors of HEIs. Although the factors may appear different in meaning from the earlier ones discovered by Brown (2016), they are more of a breakdown of his extrinsic and intrinsic factors.

\section{Blended learning extrinsic motivational factors Instructor interactions with technology}

High perceived usefulness encourages the instructors' intention to integrate technology into their teaching activities (Cigdem \& Topcu, 2015). Likewise, the absence of technological literacy slows BL applications among instructors, and frequent interaction with technology encourages the intention to blend among instructors. Therefore, the difficulties faced by faculty members with regard to technology depend on the lack of adequate technological literacy (Davis \& Fill, 2007). Information and communication technologies, in general, are an essential factor in the current educational system and research. Instructors utilize modern technology for education to train students in the best broader domains and format via collaboration, which subsequently adds to student motivation (Lyulyaeva \& Shapiro, 2018). Specific barriers to technology have been identified as facility availability, reliability and the complexity of technology itself by Reid (2014). It is also a fact that faculty members anticipate comprehensive technical support and readiness from the school regarding professional development technology training sessions, which has a significant effect on the instructor motivation to use this technology for teaching according to Nicolle and Lou (2008). The lack of access to appropriate hardware and software can slow and supress the highest motivation, as 
established by Surry, Ensminger, and Jones (2002). Additionally, when the technology infrastructure becomes unreliable, it has a negative impact on behavioural intention to blend, which will also result in negative perceptions with regard to integrating technology for education (Derntl \& Motschnig-Pitrik, 2005). Compatibility was also found to be positive and highly influential with respect to the attitudes towards the technology but not necessarily the system use itself (Cheung \& Vogel, 2013). However, Schoonenboom (2014) reported no connections between tools and tasks used by instructors in the LMS environment but also their intention to use the actual system. Therefore, from the related literature above, we can hypothesize that:

H1- Interactions of instructors with technology have a positive effect on motivation for applying blended learning

\section{Instructor academic workload}

A frequent question asked by instructors whenever they shift their focus towards the redesign process is how much time should be devoted to face-to-face classes and online activities (Owston \& York, 2018). According to Meyer and Xu (2009), one of the pressing concerns of faculty members regarding employing the services of online tools in teaching is academic workload. Blending is time demanding; there is no doubt of this, and faculty is solely responsible for the weighing of its costs. Based on the perceptions of faculty members, most of the time spent on BL practices came at the expense of research activities (Meyer \& Xu, 2009). Notably, faculty members failed to adopt instructional technology due to a lack of adequate time commitment (Drent \& Meelissen, 2008; Simpson, 2010; Zhou \& Xu, 2007). The instructional design of blending requires a time commitment, which has a negative impact on the academic workload (Birch \& Burnett, 2009). As you are designing an instructional system for one system, it may also require you to redesign to give room for system update or software changes in the future (Welker \& Berardino, 2005). Another study by Napier, Dekhane, and Smith (2011) suggests that as workload increases, the chances of blending decreases. It is also the perception of faculty to view the cost to redesign instruction with regard to blending as a time-consuming approach (Simpson, 2010). Based on this background, we propose the following hypothesis:

H2-Academic workload has a positive effect on motivation for applying blended learning.

\section{Institutional environment}

There is no doubt that the implementation of BL must go hand in hand with a change in teaching practice, which affects many HEI's core services, including content, learning interactions, assessment, credentialing, and student support plus technology. These changes demand that the role of instructors and students to be remodelled and learning responsibilities renegotiated (Gibson et al., 2016). Institutional administration regarding strategic planning, policy making or even substitute for incentive structures trigger the intention to blend (Reid, 2014; Stacey \& Gerbic, 2008). According to Benfield, Roberts, and Francis (2006), models of BL are more likely to have less problems when they align with local institutional needs. Organizational readiness to assist blended instruction (Buchanan, Sainter, \& Saunders, 2013) and systems of communication between 
students, faculty and administrators (Tabor, 2007) are also deemed vital in influencing blending. Faculty shows concerns regarding the administrative control of systems (Johnson, Wisniewski, Kuhlemeyer, Isaacs, \& Krzykowski, 2012) and the presence of institutional support (Buchanan et al., 2013; Calderon, Ginsberg, \& Ciabocchi, 2012; Reid, 2014). To make BL a success, there is an absolute need for the school to have a clear and supportive institutional policy, leadership and practice towards the idea of BL courses, as is reported to be under-represented in the BL literature according to Johnson et al. (2016). Jones, Harvey, and Lefoe (2014) developed a conceptual framework by identifying a space in which both academics and professionals can engage one another collaboratively to trigger expertise, all to address the challenges of administrative concerns for accountability and strategic intellect for blended courses. The presence of organizational structure, strategy and support fuel the BL process together with the individual decision making of instructors. While institutional decision making, strategy, structure and support encourages or discourages BL application, decisions regarding infrastructure and institutional support were found to be important motivators among the faculty members (Porter \& Graham, 2015). Accordingly, hypothesis three is proposed;

The H3-institutional environment has a positive effect on the motivation for applying blended learning.

\section{Instructor interactions with students}

According to Dahlstrom, Walker, and Dziuban (2012), students usually give positive feedback with regard to BL practice and, based on that, faculty continues to introduce online tools in their respective courses (Calderon et al., 2012; Holley \& Oliver, 2010). Students have relied less on instructors as the source of knowledge but instead as facilitators of learning (Cheung \& Vogel, 2013; Holley \& Oliver, 2010). Therefore, instructors are required to have a clear understanding of the students' motivation to engage in online or blended education (Vanslambrouck, Zhu, Lombaerts, Philipsen, \& Tondeur, 2018). It is always important to train students on how to use online tools, as indicated by Stacey and Gerbic (2008). Research on blended instruction from the African University indicates that the lack of adequate computer skills and limited access to technology discourages instructors from adopting blended instructions (Tshabala et al., 2014). Additionally, according to Wach, Broughton, and Powers (2011), a similar concern mentioned above was the problem of blending in a particular institution. Therefore, students' technological literacy becomes part of the blended course requirement according to Stacey and Gerbic (2008) and Wach et al. (2011). Therefore, based on the literature investigation and discussion above, the following hypothesis is proposed:

H4-Interactions of instructors with students have a positive effect on the motivation for applying blended learning.

\section{Blended learning intrinsic motivational factors}

Instructor attitudes and beliefs

There are two common kinds of attitude and beliefs on BL with regard to instructors in the BL literature. First, one has to do with attitude and beliefs on technology that influence and shape the decision made by the instructors. Second, attitude and beliefs 
regarding teaching were salient (Lattuca \& Stark, 2011). However, many studies have identified instructors' attitudes and beliefs regarding BL applications as a vital influencer for BL implementation (Buchanan et al., 2013; Johnson et al., 2012; Thornton, 2010). Although technological anxiety has a strong negative impact on the faculty's intention to adopt BL according to Johnson et al. (2012), at the same time, the chances of adopting BL is greater with faculty members that have a high degree of internet self-efficacy (Buchanan et al., 2013). A study of computer science instructors from Greece found a relation between pedagogical beliefs and approaches to blended instruction. Likewise, instructors' beliefs regarding teaching are said to be a significant motivator for BL application and gives many disciplines to faculty members (Lameras, Levy, Paraskakis, \& Webber, 2012). Therefore, we propose the following hypothesis:

H5- Attitudes and beliefs of instructors have a positive effect on the motivation for applying blended learning.

\section{Instructor learning}

Institutional support concerning training prepares the instructors on how to handle online tools (Porter et al., 2014). Capacity building in relation to training is the most critical support that an instructor can tap from the institution (Burton \& Bessette, 2013; Fetters \& Duby, 2011; Myers, Mixer, Wyatt, Paulus, \& Lee, 2011; Rienties, Brouwer, \& Lygo-Baker, 2013). Guidance and support from the institution are required by the instructors to aid them in utilizing online tools in teaching (Keengwe, Kidd, \& Kyei-Blankson, 2009). Additionally, professional development programmes must be made available, specifically for pedagogical and technological skills together with a good strategy (Wach et al., 2011). Organizing training programmes such as online tutorials also widen the technological skills of the instructors (Rienties et al., 2013). However, broad technological skills boost the intention of the instructors to use online tools for teaching. Being an active participant of the capacity mentioned above helped instructors to address the issue of technology anxiety and skepticism for successful implementation. Hands-on practice also shaped faculty members' perceptions of some issues regarding the quality of teaching that can be achieved using online tools (Johnson et al., 2012). Therefore, from the discussion above, the following hypothesis is proposed:

H6- Instructor learning has a positive effect on the motivation for applying blended learning.

\section{The concept of motivation with respect to $\mathrm{BL}$ application}

Motivation has to do with energy and all other aspects of initiation and intention. Although we tend to become motivated due to numerous factors that are unique to specific experiences and consequences, strong extrinsic coercion is a strong influence on individuals without a doubt (Ryan \& Deci, 2000). Copriady (2015) reported motivation as an active mediator that helps instructors become ready to apply ICT in their teaching and learning. The idea of motivation is divided into categories, extrinsic and intrinsic motivation. Extrinsic motivation is committing an action based on the perceived importance of achieving that task, while intrinsic motivation refers to acting based on interest in the action itself against extrinsic influences (Ifinedo, 2017; Lin \& Lu, 2011). 
Motivation is also regarded as a product of the interaction between a person and a particular situation and is not a personal trait. The entire process of motivation symbolizes how one's effort is encouraged, positioned and maintained towards attaining a particular goal. This process is claimed to work effectively when the individual needs are not in conflict with the target goals. According to early theories of motivation, Maslow's hierarchy of needs (theory) is divided into five levels, i.e., from lower order to higher. Individuals must satisfy lower-order needs to attain higher-order needs. Lower-order needs are termed extrinsic needs, namely, physical and safety, while higher-order needs are referred to as intrinsic needs, namely, social, esteem and self-actualization (Robbins, De Cenzo, and Coulter, 2008). Prior research has shown that perceived usefulness is a good representation of extrinsic motivation and perceived playfulness as intrinsic motivators (Chang, Hung, Cheng, \& Wu, 2015; Ifinedo, 2017). However, Herzberg's motivation theory (hygiene theory) considers motivation to be a product of two factors, namely, hygiene factors, also termed extrinsic (environmental), which are factors that are responsible for job dissatisfaction. The second factor is the motivator, referred to as intrinsic factors responsible for the creation of job satisfaction (Robbins, De Cenzo, \& Coulter, 2008). In essence, motivation theory is about behaviour and offers some clues regarding what instigates a person to intend to repeat a particular behaviour or action (Ifinedo, 2017). In addition, other studies (Chang et al., 2015; Ifinedo, 2017; Kim, Chan, \& Gupta, 2007; Lin \& Bhattacherjee, 2008; Lu \& Su, 2009; Moon \& Kim, 2001; Teo, Lim, \& Lai, 1999; Van der Heijden, 2004) all discovered perceived usefulness to be an extrinsic motivation and perceived enjoyment as an intrinsic motivator.

Moreover, it was confirmed that the two motivational factors are essential influencers to intentionally use and accept information technology. "The importance of BL to instructors is that blending can personalize learning by adjusting their pedagogy and online environment to the motivation of students, which helps them perform at more personal levels" (Vanslambrouck et al., 2018, p.34). Therefore, based on the discussions above, we hypothesize the following:

H7-Motivation for applying blended learning has a positive effect on applying blended learning.

\section{Overview of the proposed motivational model}

Considering the related literature, influential factors are commonly grouped into two categories: extrinsic and intrinsic, because they influence an individual faculty member's experience in BL practice. For extrinsic factors, determinants such as instructor interactions with technology, academic workload, institutional environment and students are found to be essential motivators for applying BL. Intrinsic factors, such as instructor attitude and beliefs regarding technology and instructor learning, are important motivating factors when applying online tools for teaching. The proposed motivation model illustrated in Fig. 1. has motivation for applying blended learning as the dependent variable and the two categories of motivational factors, which are extrinsic and intrinsic, are considered independent variables. In the other part of the model, the motivation for applying blended learning serves as the dependent variable and applying blended learning serves as an independent variable. Figure 1. is the proposed motivational model, and Table 1 presents a summary of the explanations for the model constructs. 


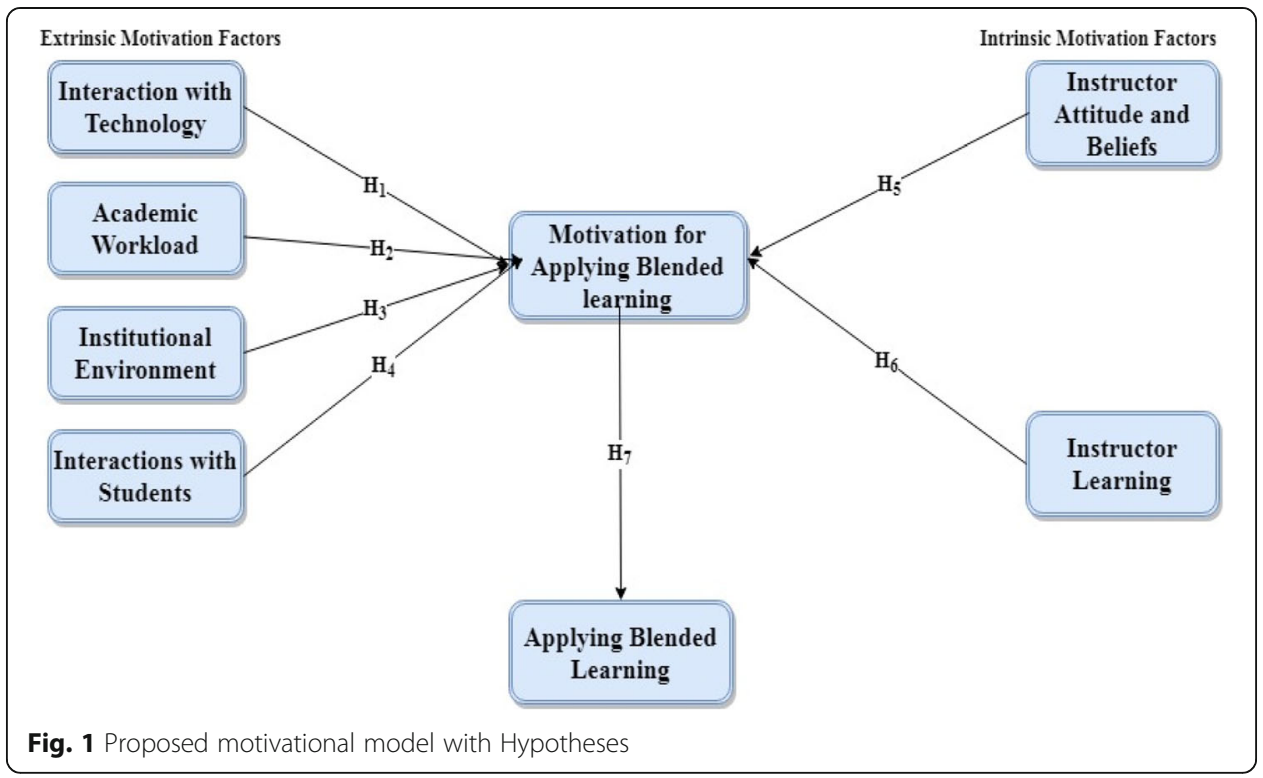

\section{Research methodology}

Development of the instrument

To develop an active survey for data collection, 31 items relevant to the 8 constructs of the proposed model are adopted from the related literature including Venkatesh, Morris, Davis, and Davis (2003), Chen (2011), Akçayır (2017), Sundaravej (2010), Wang and Wang (2009), Chiu and Wang (2008), and Roca, Chiu, and Martínez (2006). The items are refined according to the needs of this study. The questionnaires were administered to instructors across different HEIs in Turkey and North Cyprus. Items were measured based on a five-point Likert scale, ranging from (1) strongly disagree to (5) strongly agree.

\section{Data collection}

Criteria sampling was utilized to determine the instructors from the HEIs. Participation for this research was voluntary, and instructors provided their consent to participate. The

Table 1 Research Model Constructs Summary Explanation

\begin{tabular}{ll}
\hline Construct & Description \\
\hline $\begin{array}{l}\text { Instructor Interaction with } \\
\text { Technology }\end{array}$ & Instructor technological literacy due to frequent interaction with technology. \\
Academic Workload & The time required to integrate technology with instructional task. \\
Institutional Environment & Preparing the institution in terms of necessary facilities that aid blending. \\
Interaction with Students & $\begin{array}{l}\text { Retrieving positive feedback from students on what encourages migration } \\
\text { to BL. }\end{array}$ \\
$\begin{array}{ll}\text { Motivation for Applying } \\
\text { Blended Learning }\end{array}$ & $\begin{array}{l}\text { Instructor satisfaction with factors that aid BL Application in teaching. } \\
\text { Instructor Attitude and Beliefs }\end{array}$ \\
$\begin{array}{l}\text { Instructor personal attitude and beliefs with respect to integrating technology } \\
\text { with teaching and learning. } \\
\text { Applying Blended Learning }\end{array}$ & $\begin{array}{l}\text { Instructor capacity building in terms of training, seminar etc. } \\
\text { result of Applying blended learning. }\end{array}$ \\
\hline
\end{tabular}


questionnaires were administered across the instructors of different HEIs in North Cyprus and Turkey. The data were collected using both hard copy and online questionnaires. In total, 500 questionnaires were sent, 415 responses were returned, and 53 responses had missing data; therefore, 362 valid responses were evaluated. The rate of user responses for this study settled at $72.3 \%$. The tool used for the analysis was IBM SPSS/AMOS 23.

\section{Demographics data and descriptive statistics}

Table 2 presents the characteristics of the respondents: $43.6 \%$ were female and $56.4 \%$ were male. Of the respondents, $16.6 \%$ were between 25 and 30 years of age, $19.1 \%$ were between 36 and 40 years of age, and $9.4 \%$ were between 51 and above. The title demographics of the respondents indicate that $24 \%$ of the respondents are associate professors and $19.6 \%$ of the respondents are professors. The years of teaching experience, which are placed on five different categories, indicate that $23.2 \%$ of the respondents have been teaching under five years, 28.2\% have been teaching 11-15 years and 16.3\% have been teaching 20 years or greater. Additionally, $84.8 \%$ of the respondents indicate that they apply BL in their courses, while $15.2 \%$ indicate that they do not engage $\mathrm{BL}$ practice. Finally, $14.4 \%$ of the respondents indicated that they did not receive any form of training on $\mathrm{BL}$, while $61 \%$ indicated that $\mathrm{BL}$ training that they received lasted between 1 and $5 \mathrm{~h}$. Table 1 summarizes the demographic data.

\section{Results}

\section{Reliability and constructs validity analysis}

Reliability refers to the consistency of a test or measurement (Weir, 2005; the concept was used in this study to conduct a confirmatory factor analysis (CFA) of the measurement model so that the internal consistency of the data could be validated. First, the analysis of the measurement was carried out by comparing the eight-factor model (Instructor Interaction with Technology, Academic workload, Institutional environment, Instructor interactions with students, Instructor Attitude and Beliefs, Instructor learning with motivation for applying blended learning towards the final construct, applying blended learning). Internal consistency and reliability were evaluated using Cronbach's alpha coefficient analysis for each construct. If Cronbach's alpha coefficient of items for each construct is higher than 0.7 , then the items are considered highly reliable according to Kannan and Tan (2005). All the respective Cronbach's alpha coefficients of the eight constructs were greater than the recommended value of 0.7 or higher, as suggested by both Kannan and Tan (2005) and Wang and Wang (2009). The values of standardized loading estimated for all the items were higher than 0.5 , while the composite reliability (CR) was recommended to be higher than 0.7 and the average variance extracted (AVE) was higher than 0.5. Therefore, the values for the AVE and composite reliability (CR) were all higher than 0.5 and 0.7 , respectively, as recommended by Šumak and Šorgo (2016), Chauhan and Jaiswal (2016) and Tosuntaş, Karadağ, and Orhan (2015). Table 3 presents the reliability analysis.

\section{Model fit measurement}

Statistical significance levels are estimated utilizing the fit indices of the confirmatory factor analysis, as indicated in Table 4 below. Moreover, the fit indices checked are as 
Table 2 The demographic characteristics of the sample

\begin{tabular}{|c|c|c|}
\hline Category & Frequency & Percentage\% \\
\hline \multicolumn{3}{|l|}{ Gender } \\
\hline Female & 158 & 43.6 \\
\hline Male & 204 & 56.4 \\
\hline Total & 362 & 100.0 \\
\hline \multicolumn{3}{|l|}{ Age (in Years) } \\
\hline $25-30$ & 60 & 16.6 \\
\hline $31-35$ & 78 & 21.5 \\
\hline $36-40$ & 69 & 19.1 \\
\hline $41-45$ & 62 & 17.1 \\
\hline $46-50$ & 59 & 16.3 \\
\hline 51 and Above & 34 & 9.4 \\
\hline Total & 362 & 100.0 \\
\hline \multicolumn{3}{|l|}{ Title } \\
\hline Research assistant & 37 & 10.2 \\
\hline Lecturer/Instructor & 92 & 25.4 \\
\hline Assistant Professor & 75 & 20.7 \\
\hline Associate Professor & 87 & 24.0 \\
\hline Professor & 71 & 19.6 \\
\hline Total & 362 & 100.0 \\
\hline \multicolumn{3}{|c|}{ Years of Teaching experience } \\
\hline Under 5 & 84 & 23.2 \\
\hline $6-10$ & 64 & 17.7 \\
\hline $11-15$ & 102 & 28.2 \\
\hline $16-20$ & 53 & 14.6 \\
\hline 20 and above & 59 & 16.3 \\
\hline Total & 362 & 100.0 \\
\hline \multicolumn{3}{|c|}{ Do you Apply BL to your course(s) } \\
\hline Yes & 307 & 84.8 \\
\hline No & 55 & 15.2 \\
\hline Total & 362 & 100.0 \\
\hline \multicolumn{3}{|l|}{ Received training in BL } \\
\hline None & 52 & 14.4 \\
\hline $1-5$ Hours & 221 & 61.0 \\
\hline More than 5 Hours & 89 & 24.6 \\
\hline Total & 362 & 100.0 \\
\hline
\end{tabular}

follows: goodness-of-fit index (GFI), adjusted goodness-of-fit index (AGFI), root mean square error approximation (RMSEA), normalized fit index (NFI), comparative fit index (CFI) and ratio of chi-square to the degree of freedom, i.e., $x^{2} / d f$, which are very important to use as the major indicator of goodness-of-fit. If all values satisfy the recommended values, then it is an indication that the data collected are appropriate to the scale items and the model's goodness-of-fit indices signify that the model proposed for the scale is appropriate. Therefore, at this stage, a statistically compatible model with 
Table 3 Result for Reliability and Constructs validity test

\begin{tabular}{|c|c|c|c|c|c|}
\hline Construct & Items & $C R$ & AVE & Factor loading & Cronbach's alpha \\
\hline \multirow[t]{4}{*}{ AW } & AW1 & 0.873 & 0.633 & 0.84 & 0.871 \\
\hline & AW 2 & & & 0.78 & \\
\hline & AW 3 & & & 0.75 & \\
\hline & AW 4 & & & 0.80 & \\
\hline \multirow[t]{4}{*}{$\mathrm{IE}$} & $\mathrm{IE} 1$ & 0.908 & 0.711 & 0.82 & 0.906 \\
\hline & $\mathrm{IE} 2$ & & & 0.83 & \\
\hline & IE3 & & & 0.86 & \\
\hline & IE4 & & & 0.86 & \\
\hline \multirow[t]{4}{*}{ MA } & MA1 & 0.883 & 0.654 & 0.82 & 0.882 \\
\hline & MA2 & & & 0.82 & \\
\hline & MA3 & & & 0.84 & \\
\hline & MA4 & & & 0.75 & \\
\hline \multirow[t]{4}{*}{$A B$} & $A B 1$ & 0.845 & 0.645 & 0.81 & 0.845 \\
\hline & AB2 & & & 0.83 & \\
\hline & $\mathrm{AB} 3^{\mathrm{a}}$ & & & 0.44 & \\
\hline & $\mathrm{AB} 4$ & & & 0.77 & \\
\hline \multirow[t]{4}{*}{ IT } & IT1 & 0.880 & 0.649 & 0.69 & 0.870 \\
\hline & IT2 & & & 0.87 & \\
\hline & IT3 & & & 0.92 & \\
\hline & IT4 & & & 0.72 & \\
\hline \multirow[t]{4}{*}{ is } & IS1 & 0.803 & 0.505 & 0.73 & 0.802 \\
\hline & 152 & & & 0.72 & \\
\hline & 153 & & & 0.70 & \\
\hline & 154 & & & 0.69 & \\
\hline \multirow[t]{4}{*}{ IL } & IL1 & 0.871 & 0.629 & 0.73 & 0.866 \\
\hline & IL2 & & & 0.86 & \\
\hline & IL3 & & & 0.84 & \\
\hline & IL4 & & & 0.73 & \\
\hline \multirow[t]{3}{*}{ ABL } & ABL1 & 0.842 & 0.640 & 0.82 & 0.841 \\
\hline & ABL2 & & & 0.79 & \\
\hline & ABL3 & & & 0.80 & \\
\hline
\end{tabular}

\footnotetext{
${ }^{a}$ : deleted
}

NB: IL Instructor learning, AW Academic Workload, IE Institutional Environment, MA Motivation for applying blended learning, $A B$ Instructor Attitude \& Beliefs, IT Instructor Interaction with Technology, IS Instructor Interaction with Students, $A B L$ Applying Blended learning

the relationships between variables would be obtained. Table 4 presents the values for the model fit indices.

However, if the ratio of $x^{2}$ to the degree of freedom $\mathrm{df}\left(\mathrm{x}^{2} / \mathrm{df}\right)$ value is less than 3 , then the model fit is acceptable, and it is 1.55 . Other fit indices results include the GFI, which is 0.9 , and the RMSEA, which settled at 0.039. The AGFI is 0.8, the NFI is 0.9, and the CFI is 0.9. As presented in Table 4, all these fit indices are in the recommended ranges, as suggested by Wang and Wang (2009); El-Masri and Tarhini (2017) and Hassanzadeh, Kanaani, and Elahi (2012). Moreover, with the findings from all these fit indices used, it is a good indication that the data used in this study affirmed to have reasonable compatibility with the proposed model. Next, the discriminant validity, 
Table 4 Model Fit indices

\begin{tabular}{lll}
\hline Fit indices & Recommended value & Structural Model \\
\hline$x 2 /$ df & $<3$ & $587.24 / 377=1.558$ \\
$P(p$-value $)$ & $>0.05$ & 0.999 \\
GFI & $>0.9$ & 0.904 \\
RMSEA & $<0.08$ & 0.039 \\
AGFI & $>0.8$ & 0.881 \\
NFI & $>0.9$ & 0.913 \\
CFI & $>0.95$ & 0.967 \\
\hline
\end{tabular}

which provides evidence on the internal and external validity of the measurement instrument and scales for the construct, was checked, which was also determined by comparing the squared correlation between the two constructs and their AVE values. All of the squared correlations were found to be less than the average variance extracted values, which indicates sufficient discriminant validity as recommended by Cheung and To (2016), Prasad, Maag, Redestowicz, and Hoe (2018), and Mohammadi (2015) Table 5 presents the discriminant validity values for the constructs.

Convergent validity measures suggest that items can effectively reflect on their corresponding factors (Mohammadi, 2015), and it was investigated using the Cronbach alpha, AVE and CR. Hence, the three criteria for measuring the convergent validity were all attained according to the recommended values. The Cronbach's alpha of the entire construct exceeded the minimum value of 0.7 , and the composite reliabilities of the factors fulfilled the required minimum value of 0.7 , whereas the average extracted variance attained the required value of 0.5 , as shown in Table 3 above.

\section{Hypothesis testing}

After establishing a good reliability test, convergent and discriminant validity, the regression analysis was used to test the hypotheses. The values of the standardized coefficient $(\beta)$, standard error and $t$-value were considered to determine if all the relationship points in the assumed direction were statistically significant. Table 6 displays the

Table 5 Discriminant validity

\begin{tabular}{lllllllll}
\hline & $\mathrm{IL}$ & $\mathrm{AW}$ & $\mathrm{IE}$ & $\mathrm{MA}$ & $\mathrm{AB}$ & $\mathrm{IT}$ & $\mathrm{IS}$ & $\mathrm{ABL}$ \\
\hline $\mathrm{IL}$ & 0.793 & & & & & & & \\
AW & 0.504 & 0.795 & & & & & & \\
IE & 0.371 & 0.403 & 0.843 & & & & & \\
MA & 0.516 & 0.388 & 0.463 & 0.809 & & & & \\
AB & 0.492 & 0.380 & 0.299 & 0.529 & 0.803 & & & \\
IT & 0.383 & 0.276 & 0.340 & 0.522 & 0.635 & 0.806 & & \\
IS & 0.335 & 0.407 & 0.421 & 0.385 & 0.297 & 0.230 & 0.711 & \\
ABL & 0.556 & 0.431 & 0.402 & 0.751 & 0.618 & 0.633 & 0.372 & 0.800 \\
\hline
\end{tabular}

Note: Diagonals stands for the average variance extracted, and the other matrix entries represent the squared factor correlations

NB: IL Instructor learning, AW Academic Workload, IE Institutional Environment, MA Motivation for applying blended learning, $A B$ Instructor Attitude \& Beliefs, IT Instructor Interaction with Technology, IS Instructor Interaction with Students, $A B L$ Applying Blended learning 
Table 6 Results in Summary

\begin{tabular}{|c|c|c|c|c|c|c|c|}
\hline \multicolumn{4}{|c|}{ Hypotheses and pathways } & \multirow{2}{*}{$\frac{\text { Standardized coefficient }(\beta)}{0.256^{* * *}}$} & \multirow{2}{*}{$\frac{\text { Std. error }}{0.066}$} & \multirow{2}{*}{$\frac{\text { t-value }}{4.000}$} & \multirow{2}{*}{$\begin{array}{l}\text { Result } \\
\text { Supported }\end{array}$} \\
\hline $\mathrm{H} 1$ & IT & $\rightarrow$ & MA & & & & \\
\hline $\mathrm{H} 2$ & AW & $\rightarrow$ & MA & 0.031 & 0.540 & 0.540 & Not supported \\
\hline H3 & IE & $\rightarrow$ & MA & $0.181 * * *$ & 0.042 & 3.332 & Supported \\
\hline $\mathrm{H} 4$ & IS & $\rightarrow$ & MA & $0.119 *$ & 0.045 & 2.095 & Supported \\
\hline H5 & $A B$ & $\rightarrow$ & MA & $0.189 * *$ & 0.065 & 2.701 & Supported \\
\hline $\mathrm{H} 6$ & $\mathrm{IL}$ & $\rightarrow$ & MA & $0.231 * * *$ & 0.059 & 3.792 & Supported \\
\hline $\mathrm{H} 7$ & MA & $\rightarrow$ & $A B L$ & $0.789 * * *$ & 0.052 & 12.847 & Supported \\
\hline
\end{tabular}

Note: ${ }^{*} \mathrm{p}<0.10,{ }^{* *} \mathrm{p}<0.05,{ }^{* * *} \mathrm{p}<0.01$

NB: IL Instructor learning, AW Academic Workload, IE Institutional Environment, MA Motivation for applying blended learning, $A B$ Instructor Attitude \& Beliefs, IT Instructor Interaction with Technology, IS Instructor Interaction with Students, $A B L$ Applying Blended learning

complete regression test values and pathway analysis for the model. Likewise, Fig. 2 presents the result of the structural equation model.

\section{Structural model and path analysis}

The model structure was investigated after checking the constructs with the measurement model. We used the structural equation modelling method to establish the relationship between the constructs for the proposed model through the use of the maximum likelihood estimation method. The SEM approach was considered by examining the standardized beta coefficients and t-values of the hypothesized model. The chi-square result for the structural equation model is 587.24, while the degree of freedom is at 377 ; therefore, the ratio of $\mathrm{x}^{2}$ to $\mathrm{df}=587.24 / 377=1.5$, which is a clear pass to proceed with the hypothesis testing. However, factors such as instructor interactions with technology, academic workload, institutional environment, instructor interaction with students, instructor attitude and beliefs and instructor learning are the independent variables and motivation for applying blended learning is the dependent variable. Furthermore, the model actual end result factor "applying blended learning" is

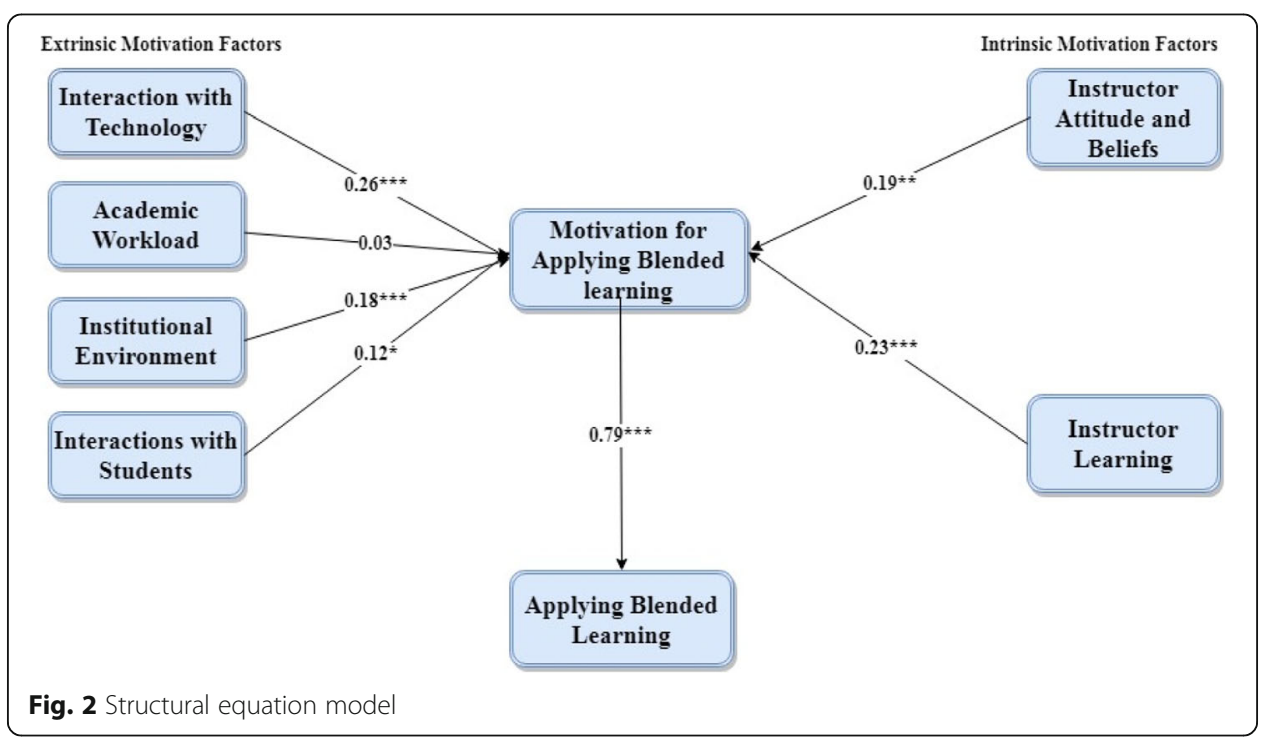


considered as the dependent variable with its independent variable as motivation for applying blended learning. Table 6 shows the standardized estimates, standard errors and significance levels for the respective construct hypotheses. For hypotheses number one (H1) and three (H3), if frequent instructor interactions with technology and the institutional environment have a positive effect on the motivation for applying blended learning, then the path coefficient values as indicated in Table 6 were determined as $\beta$ $=0.256, P<0.01 ; \beta=0.181$, and $P<0.01$. Thus, these values indicate a highly significant level of support for the two hypotheses, one (H1) and three (H3). Hypothesis two (H2) examines whether academic workload has a positive effect on the motivation for applying blended learning. An examination of the beta coefficient value $(\beta=0.031)$ shows that the academic workload does not influence the motivation for applying $B L$; therefore, the hypothesis is rejected. However, hypotheses four (H4) and five (H5) test the positive effect linkages between instructor interactions with students and instructor attitude and beliefs with the motivation for applying blended learning. The AMOS-SEM finding for the path coefficient values $(\beta=0.119, P<0.10 ; \beta=0.189, P<0.05)$ disclosed that both instructor interactions with students and instructor attitude and beliefs had a significant effect on the motivation for applying blended learning; therefore, the hypotheses are supported. Alternatively, hypotheses six (H6) and seven (H7) test the influence of instructor learning on the motivation for applying blended learning and motivation for applying blended learning on applying blended learning. The results path coefficients revealed values as follows: $\beta=0.231, P<0.01$ and $\beta=0.789, \mathrm{P}<0.01$, confirming that instructor learning is a significant predictor for the motivation for applying blended learning. Additionally, the linkage of the motivation for applying blended learning with applying blended learning revealed a significant positive effect on the instructors. This strength is due to the strong bonds attained between the independent factors on the dependent factors (motivation for applying blended learning); hence, hypotheses six and seven were endorsed.

\section{Discussion}

This study explored some factors responsible for the motivation of BL among instructors of HEIs and designed and tested a theoretical motivational model for BL. Hypothesis one (H1), instructor interactions with technology have a positive effect on the motivation for applying $B L$, shows a highly significant relationship between the instructor's frequent interactions with technology and the motivation for applying blended learning. This hypothesis is in line with the findings of Cigdem and Topcu (2015), Davis and Fill (2007), and Nicolle and Lou (2008), which imply that frequent instructor interactions with technology have a positive influence on the instructor's motivation to apply BL. Therefore, it is important for instructors to be technology savvy for integrating technologies into their courses. Additionally, this knowledge can increase the level of confidence and motivation of the instructors for successful BL implementation.

Hypothesis two (H2), which hypothesized that the academic workload has a positive effect on the motivation for applying blended learning, was not supported, which implies that the academic workload does not influence the instructors' motivation for applying blended learning. This result also agrees with the findings in the literature by Meyer and Xu (2009), Drent and Meelissen (2008), Simpson (2010), Zhou and Xu 
(2007), Birch and Burnett (2009), Napier et al. (2011), and Simpson (2010), who all report that blending is time consuming and increases the academic workload, which has a negative impact on instructor motivation towards the whole idea of blending. Therefore, it is clear that delivering a BL course comes with a price of increased academic workload for the faculty. It has now become imperative to be specific with course requirements and instructions while designing a BL environment to reduce the workload on instructors and enhance their motivation; hence, this hypothesis was not supported.

However, hypothesis three (H3), which checked the positive effect of the institutional environment on the motivation for applying blended learning, displayed a strong positive relationship between the right facility/policy in the institutional environment with instructor motivation towards blending. This finding is also in agreement with previous studies by Reid (2014), Stacey and Gerbic (2008), Buchanan et al. (2013), Calderon et al. (2012), Johnson et al. (2016), Jones et al. (2014), and Porter and Graham (2015), in which these authors state decisions regarding infrastructure and institutional support as vital motivators among instructors towards BL practice. The technological readiness of the institutions is an important factor in promoting BL practices. The absence of strong technological readiness discourages instructors with respect to BL. As a result, instructors would rather spend much of their instructional time managing technical problems associated with the poor system.

Moreover, hypothesis four (H4), Instructor interactions with students, showed a significant positive effect on motivation for applying blended learning. This significant finding is in line with those who reported (Dahlstrom et al., 2012; Stacey \& Gerbic, 2008; Wach et al., 2011) instructor interactions with students to normally results in retrieving positive feedback with regards to BL practice. Therefore, while considering BL implementation, it is important for the instructor to understand the students' perceptions of BL technology as a whole. Probing is necessary, especially in the area of ease of use, with respect to the students' familiarity with the BL environment. Flexibility in the sense that students demonstrate a more timely submission of homework, i.e., it is easier to post an assignment online rather than the traditional way of typing, printing and then driving to campus to submit it. Additionally, the ability to verify electronically if all assignments have been submitted and verify adequate interaction time between the instructors and students. Students can have access to course materials any day and any time with rapid responses for their feedback from the instructor. All of these factors must be understood by the instructors to ascertain their students' readiness to BL, which will subsequently add to their motivation. Hence, in the context of this study, the hypothesis was upheld. Hypothesis five (H5) revealed some level of significance between the constructs, instructor attitudes and beliefs and instructor motivation for blended learning. This finding is in agreement with the findings of Buchanan et al. (2013), Johnson et al. (2012), Thornton (2010), and Lameras et al. (2012), who state that instructor attitude and beliefs with regard to BL is a mediating factor to motivation for applying blended learning. Therefore, the chances of adopting BL are greater with an instructor that has a high degree of internet self-efficacy. Moreover, this factor corroborates the fact that there is a relationship between pedagogical beliefs and approaches to blended instruction. The instructors' attitude and beliefs regarding teaching are confirmed as a significant motivator for the application of BL with a considerable sense of discipline to the faculty members; hence, the hypothesis was supported. 
For hypothesis number six (H6) instructor learning, there is a highly significant positive effect of the model construct with the motivation for applying blended learning. This finding is in line with the results of previously reported literature, which emphasized institutional support concerning training to prepare the faculty on how to handle online tools (Porter et al., 2014). Additionally, capacity building in relation to training is the most important support to give to the instructors by the institution, as affirmed by Burton and Bessette (2013), Fetters and Duby (2011), Johnson et al. (2012), Rienties et al. (2013). It is therefore very important to plan and coordinate periodic training, workshops and seminars for instructor development in the aspect of BL. Furthermore, training can add to instructor motivation towards a successful BL implementation. Hypothesis seven (H7), construct the motivation for applying blended learning, has a positive effect on the model's final construct, applying blended learning. This hypothesis is also in agreement with the findings that emphasize motivation as the energy and all other aspects of initiation and intention towards achieving a goal according to Ifinedo (2017), Chang et al. (2015), Ryan and Deci (2000), Robbins De Cenzo and Coulter (2008). These results show that motivation is a strong mediator that encourages instructors to be ready to apply BL to their teaching and learning, as is confirmed by Copriady (2015).

Moreover, with the confirmation of the motivation model as an important mediating factor for BL implementation, the extrinsic and intrinsic motivational factors have a strong positive influence on instructors' motivation towards BL application in HEIs. It is also vital for any HEI to examine their instructor satisfaction/motivation on any form of technology before considering its final implementation. This model can serve as a framework to that effect, and the HEIs are free to explore and add any other factor that might add to their instructor's motivation concerning the BL environment.

\section{Conclusion}

In this study, a motivational model for predicting instructors' motivation for applying a $\mathrm{BL}$ approach in the context of HEIs is developed. The proposed model is empirically examined using the structural equation modelling method. The results provide convincing support for the proposed model. Six out of the seven hypothesized relationships between the model factors were found to be significant, giving greater insight into the instructor motivation for BL in the context of HEIs. However, the proposed model not only can predict instructors' motivation towards BL practice but also all faculty members can use it to probe the possible reasons for the lack of motivation for BL. Therefore, adjustment strategies can be proposed to have the user's theoretical and practical understanding of a BL system that is viable to instructors and their respective institutions. The study contributes to a body of BL literature by exploring the causes of BL motivation among the instructors at HEIs. In addition, most importantly, the study presents a practical solution to the user's theoretical and empirical understanding of a design model system that can support instructors in an effective BL practice. The design of the proposed model and findings also have tremendous potential value to policy-makers, educational managers, curriculum designers and the entire faculty members in creating a cohesive and effective BL environment in HEIs. 


\section{Research limitations and future studies}

Similar to many other studies, this research has its own limitations. The first major challenge encountered by the researchers is in the area of data collection. The participants, important members of the faculty, are always busy; thus, there was a delay in retrieving the questionnaires. The same experience occurred with the online version of the questionnaire; the researchers had to send a reminder and waited for some time to collect the required data. The second challenge was related to the scientific quality and interpretation of the research data, which includes ensuring that the data passed the reliability and model fit indices test to proceed with the study. The researchers managed the issues professionally by ensuring the data are free from random error; an internal consistency was established, and model fit indices were realized.

However, the motivational model designed here in this study is only applicable to instructors of HEIs; it does not extend beyond instructors of other types of learning institutions, such as high schools. Hence, there is a need for further research that can expand the scope of this study beyond the different classes of instructors with their respective institutions. To make this idea more comprehensive, we encourage further investigations and discoveries for more factors responsible for motivating instructors towards a BL approach. Additionally, these studies will provide a more complete idea of the motivation towards the effective application of BL across different categories of instructors with their institutions.

\section{Acknowledgements}

The authors would like to acknowledge the reviewers of this article both known and anonymous for their insightful comments, which added to the quality of the paper.

Funding

The authors declare no funding source for this research.

Availability of data and materials

The datasets generated during this study are available from the corresponding author on reasonable request and with the permission of the author's institution.

\section{Authors' contributions}

Corresponding author handled the research part of the study including questionnaire administering and data analysis. While second author handled questionnaire development, research design, structuring and editing. All authors read and approved the final manuscript.

Competing interests

The authors declare that they have no competing interests on the development of this article.

\section{Publisher's Note}

Springer Nature remains neutral with regard to jurisdictional claims in published maps and institutional affiliations.

Received: 17 December 2018 Accepted: 1 April 2019

Published online: 02 May 2019

References

Aguti, B., Wills, G. B., \& Walters, R. J. (2014). An evaluation of the factors that impact on the effectiveness of blended elearning within universities. In International conference on information society (i-society), (pp. 117-121). IEEE). https://doi. org/10.1109/i-Society.2014.7009023.

Akçayır, G. (2017). Why do Faculty members use or not use social networking sites for education? Computers in Human Behavior, 71, 378-385.

Al-Busaidi, K. A. (2013). An empirical investigation is linking learners' applying of blended learning to their intention of full elearning. Behaviour \& Information Technology, 32(11), 1168-1176.

Benfield, G., Roberts, G., \& Francis, R. (2006). The undergraduate experience of blended e-learning: A review of UK literature and practice. London: Higher Education Academy.

Benson, V., \& Kolsaker, A. (2015). Instructor approaches to blended learning: A tale of two business schools. The International Journal of Management Education, 13(3), 316-325.

Birch, D., \& Burnett, B. (2009). Bringing academics on board: Encouraging institution-wide diffusion of e-learning environments. Australasian Journal of Educational Technology, 25(1), 117-134. 
Bocconi, S., \& Trentin, G. (2014). Modelling blended solutions for higher education: Teaching, learning, and assessment in the network and Mobile technology era. Educational Research and Evaluation, 20(7-8), 516-535.

Brown, M. G. (2016). Blended instructional practice: A review of the empirical literature on instructors' adoption and use of online tools in face-to-face teaching. The Internet and Higher Education, 31, 1-10.

Buchanan, T., Sainter, P., \& Saunders, G. (2013). Factors affecting faculty use of learning technologies: Implications for models of technology adoption. Journal of Computing in Higher Education, 25(1), 1-11. https://doi.org/10.1007/s12528-013-9066-6.

Burton, S. L., \& Bessette, D. (2013). Understanding and applying technology in faculty development programs, (p. 2013). Fort Worth: Paper presented at IADIS International Conference on Cognition and Exploratory Learning in the Digital Age.

Calderon, O., Ginsberg, A. P., \& Ciabocchi, L. (2012). Multidimensional assessment of pilot blended learning programs: Maximizing program effectiveness based on student and faculty feedback. Journal of Asynchronous Learning Networks, 16(4), 23-37.

Çardak, Ç. S., \& Selvi, K. (2016). Increasing teacher Candidates' ways of interaction and levels of learning through action research in a blended course. Computers in Human Behavior, 61, 488-506.

Chang, C. C., Hung, S. W., Cheng, M. J., \& Wu, C. Y. (2015). Exploring the intention to continue using social networking sites: The case of Facebook. Technological Forecasting and Social Change, 95, 48-56.

Chauhan, S., \& Jaiswal, M. (2016). Determinants of acceptance of ERP software training in business schools: Empirical investigation using UTAUT model. The International Journal of Management Education, 14(3), $248-262$.

Chen, J. L. (2011). The effects of education compatibility and technological expectancy on e-learning acceptance. Computers \& Education, 57(2), 1501-1511.

Cheung, M. F., \& To, W. M. (2016). Service co-creation in social media: An extension of the theory of planned behaviour. Computers in Human Behavior, 65, 260-266.

Cheung, R., \& Vogel, D. (2013). Predicting user acceptance of collaborative technologies: An extension of the technology acceptance model for e-learning. Computers \& Education, 63, 160-175.

Chiu, C. M., \& Wang, E. T. (2008). Understanding web-based learning continuance intention: The role of subjective task value. Information \& Management, 45(3), 194-201.

Cigdem, H., \& Topcu, A. (2015). Predictors of instructors' behavioral intention to use learning management system: A Turkish vocational college example. Computers in Human Behavior, 52, 22-28.

Cochran-Smith, M., \& Lytle, S. L. (1999). Relationships of knowledge and practice: Teacher learning in communities. Review of Research in Education, 24, 249. https://doi.org/10.2307/1167272

Copriady, J. (2015). Self-motivation as a mediator for teachers' readiness in applying ICT in teaching and learning. ProcediaSocial and Behavioral Sciences, 176, 699-708.

Dahlstrom, E., Walker, J. D., \& Dziuban, C. (2012). ECAR study of undergraduate students and information technology, 2012. Boulder: CO: EDUCAUSE Center for Applied Research.

Davis, H. C., \& Fill, K. (2007). Embedding blended learning in a university's teaching culture: Experiences and reflections. British Journal of Educational Technology, 38, 817-828. https://doi.org/10.1111/j.1467-8535.2007.00756.x.

Derntl, M., \& Motschnig-Pitrik, R. (2005). The role of structure, patterns, and people in blended learning. The Internet and Higher Education, 8(2), 111-130.

Drent, M., \& Meelissen, M. (2008). Which factors obstruct or stimulate teacher educators to use ICT innovatively? Computers in Education, 51(1), 187-199.

Driscoll, M. (2002). Blended learning: Let's get beyond the hype. e-learning, 1(4), 1-4.

El-Masri, M., \& Tarhini, A. (2017). Factors affecting the adoption of e-learning systems in Qatar and USA: Extending the unified theory of acceptance and use of technology 2 (UTAUT2). Educational Technology Research and Development, 65(3), 743-763.

Fetters, M. L., \& Duby, T. G. (2011). Faculty development: A stage model matched to blended learning maturation. Journal of Asynchronous Learning Networks, 15(1), 77-86.

Gibson, D., Broadley, T., \& Downie, J. (2016). Blended learning in a converged model of university transformation. In Blended Learning for Quality Higher Education: Selected Case Studies on Implementation from Asia-Pacific (pp. 235-263). UNESCO.

Hassanzadeh, A., Kanaani, F., \& Elahi, S. (2012). A model for measuring e-learning systems success in universities. Expert Systems with Applications, 39(12), 10959-10966.

Holley, D., \& Oliver, M. (2010). Student engagement and blended learning: Portraits of risk. Computers \& Education, 54(3), 693-700.

Hora, M. T. (2012). Organizational factors and instructional decision-making: A cognitive perspective. The Review of Higher Education, 35(2), 207-235.

Ifinedo, P. (2017). Examining students' intention to continue using blogs for learning: Perspectives from technology acceptance, motivational, and social-cognitive frameworks. Computers in Human Behavior, 72, 189-199.

Jani, J., Muszali, R., Nathan, S., \& Abdullah, M. S. (2018). Blended learning approach using frog vle platform towards students'achievement in teaching games for understanding. Journal of Fundamental and Applied Sciences, 10(5S), 1130-1141.

Johnson, L., Becker, S. A., Cummins, M., Estrada, V., Freeman, A., \& Hall, C. (2016). NMC horizon report: 2016 higher education edition (pp. 1-50). The New Media Consortium. United States.

Johnson, T., Wisniewski, M. A., Kuhlemeyer, G., Isaacs, G., \& Krzykowski, J. (2012). Technology adoption in higher education: Overcoming anxiety through faculty boot camp. Journal of Asynchronous Learning Networks, 16(2), 63-72.

Jones, S., Harvey, M., \& Lefoe, G. (2014). A conceptual approach for blended leadership for tertiary education institutions. Journal of Higher Education Policy and Management, 36(4), 418-429.

Kannan, V. R., \& Tan, K. C. (2005). Just in time, total quality management, and supply chain management: Understanding their linkages and impact on business performance. Omega, 33(2), 153-162.

Keengwe, J., Kidd, T., \& Kyei-Blankson, L. (2009). Faculty and technology: Implications for faculty training and technology leadership. Journal of Science Education and Technology, 18(1), 23-28. https://doi.org/10.1007/s10956-008-9126-2.

Kim, H. W., Chan, H. C., \& Gupta, S. (2007). Value-based adoption of Mobile internet: An empirical investigation. Decision Support Systems, 43, 111-126.

Lameras, P., Levy, P., Paraskakis, I., \& Webber, S. (2012). Blended university teaching using virtual learning environments: Conceptions and approaches. Instructional Science, 40(1), 141-157. https://doi.org/10.1007/s11251 011-9170-9.

Lattuca, L. R., \& Stark, J. S. (2011). Shaping the college curriculum: Academic plans in context. San Francisco: Wiley. 
Lim, C. P., \& Wang, T. (2016). A framework and self-assessment tool for building the capacity of higher education institutions for blended learning. In Blended learning for quality higher education: Selected case studies on implementation from AsiaPacific, (pp. 1-38).

Lin, C. P., \& Bhattacherjee, A. (2008). Elucidating individual intention to use interactive information technologies: The role of network externalities. International Journal of Electronic Commerce, 13, 85-108.

Lin, K. Y., \& Lu, H. P. (2011). Why people use social networking sites: An empirical study integrating network externalities and motivation theory. Computers in Human Behavior, 27(3), 1152-1161.

Lu, H. P., \& Su, Y. J. P. (2009). Factors affecting purchase intention on Mobile shopping websites. Internet Research, 19, 442-458.

Lu, O. H., Huang, A. Y., Huang, J. C., Lin, A. J., Ogata, H., \& Yang, S. J. (2018). Applying learning analytics for the early prediction of Students' academic performance in blended learning. Journal of Educational Technology \& Society, $21(2), 220-232$

Lu, X., Zhao, G., \& Jiang, J. (2012, August). Influential Factors of Blended Learning in Chinese Colleges: From the Perspective of Instructor's Acceptance and Students' Satisfaction. In International Conference on Hybrid Learning (pp. 186-197). Berlin: Springer.

Lyulyaeva, N. A., \& Shapiro, E. D. (2018). Blended learning in teaching EFL to different age groups. The Impact of Information on Modern Humans, 622, 380

Means, B., Toyama, Y., Murphy, R., \& Baki, M. (2013). The effectiveness of online and blended learning: A meta-analysis of the empirical literature. Teachers College Record, 115(3), 1-47.

Meyer, K. A., \& Xu, Y. J. (2009). A Causal Model of Factors Influencing Faculty Use of Technology. Journal of Asynchronous Learning Networks, 13(2), 57-70.

Mohammadi, H. (2015). Investigating users' perspectives on e-learning: An integration of TAM and IS success model. Computers in Human Behavior, 45, 359-374.

Moon, J. W., \& Kim, Y. G. (2001). Extending the TAM for a world-wide-web context. Information \& Management, 38, $217-230$.

Myers, C. R., Mixer, S. J., Wyatt, T. H., Paulus, T. M., \& Lee, D. S. (2011). Making the move to blended learning: Reflections on a faculty development program. International Journal of Nursing Education Scholarship, 8(1).

Napier, N. P., Dekhane, S., \& Smith, S. (2011). Transitioning to blended learning: Understanding student and faculty perceptions. Journal of Asynchronous Learning Networks, 15(1), 20-32.

Nicolle, P. S., \& Lou, Y. (2008). Technology adoption into teaching and learning by mainstream university faculty: A mixed methodology study revealing the "how, when, why, and why not". Journal of Educational Computing Research, 39(3), 235-265. https://doi.org/10.2190/EC.39.3.c.

Oakley, G., (2016). From Diffusion to Explosion: Accelerating Blended Learning at the University of Western Australia. Blended, p. 67. UNESCO 2016, United State.

Owston, R., \& York, D. N. (2018). The nagging question when designing blended courses: Does the proportion of time devoted to online activities matter? The Internet and Higher Education, 36, 22-32.

Patchan, M. M., Schunn, C. D., Sieg, W., \& McLaughlin, D. (2016). The effect of blended instruction on accelerated learning. Technology, Pedagogy and Education, 25(3), 269-286.

Porter, W. W., \& Graham, C. R. (2015). Institutional drivers and barriers to faculty adoption of blended learning in higher education. British Journal of Educational Technology. https://doi.org/10.1111/bjet.12269.

Porter, W. W., Graham, C. R., Bodily, R. G., \& Sandberg, D. S. (2016). A qualitative analysis of institutional drivers and barriers to blended learning adoption in higher education. The Internet and Higher Education, 28, 17-27.

Porter, W. W., Graham, C. R., Spring, K. A., \& Welch, K. R. (2014). Blended learning in higher education: Institutional adoption and implementation. Computers \& Education, 75, 185-195.

Prasad, P. W. C., Maag, A., Redestowicz, M., \& Hoe, L. S. (2018). Unfamiliar technology: Reaction of international students to blended learning. Computers \& Education, 122, 92-103.

Ramirez-Arellano, A., Bory-Reyes, J., \& Hernández-Simón, L. M. (2018). Emotions, motivation, cognitive-metacognitive strategies, and behavior as predictors of learning performance in blended learning. Journal of Educational Computing Research. https://doi.org/10.1177/0735633117753935.

Reid, P. (2014). Categories for barriers to adoption of instructional technologies. Education and Information Technologies, 19(2), 383-407.

Rienties, B., Brouwer, N., \& Lygo-Baker, S. (2013). The effects of online professional development on higher education teachers' beliefs and intentions towards learning facilitation $\mathrm{n}$ and technology. Teaching and Teacher Education, 29, 122131. https://doi.org/10.1016/j.tate.2012.09.002.

Robbins, S. P., DeCenzo, D. A., \& Coulter, M. K. (2008). Fundamentals of management: Essential concepts and applications. Upper Saddle River, NJ: Pearson Prentice Hall.

Roca, J. C., Chiu, C. M., \& Martínez, F. J. (2006). Understanding e-learning continuance intention: An extension of the technology acceptance model. International Journal of Human-Computer Studies, 64(8), 683-696.

Rolfe, V. E., \& Gray, D. (2011). Are multimedia resources effective in life science education? A meta-analysis. Bioscience Education, 18(1), 1-14.

Roseth, C., Akcaoglu, M., \& Zellner, A. (2013). Blending synchronous face-to-face and computer-supported cooperative learning in a hybrid doctoral seminar. TechTrends, 57(3), 54-59.

Ryan, R. M., \& Deci, E. L. (2000). Self-determination theory and the facilitation of intrinsic motivation, social development, and well-being. American Psychologist, 55(1), 68.

Schechter, R. L., Kazakoff, E. R., Bundschuh, K., Prescott, J. E., \& Macaruso, P. (2017). Exploring the impact of engaged teachers on implementation fidelity and reading skill gains in a blended learning reading program. Reading Psychology, 38(6), 553-579.

Schoonenboom, J. (2014). Using an adapted, task-level technology acceptance model to explain why instructors in higher education intend to use some learning management system tools more than others. Computers \& Education, 71, 247-256.

Sheffield, S. L. M., McSweeney, J. M., \& Panych, A. (2015). Exploring future Teachers' awareness, competence, confidence, and attitudes regarding teaching online: Incorporating blended/online experience into the teaching and learning in higher education course for graduate students. The Canadian Journal of Higher Education, 45(3), 1. 
Simpson, C. M. (2010). Examining the relationship between institutional mission and faculty reward for teaching via distance. Online Journal of distance learning administration, 13(1), 1-13. Available at: http://www.eric.ed.gov/ERICWebPortal/ detail?accno=EJ877535. Accessed Dec 20th 2016.

Singh, R., \& Kaurt, T., (2016). 4. Blended Learning-Policies in Place at Universiti Sains Malaysia. Blended, p.103. UNESCO, 2016, United States.

Stacey, E., \& Gerbic, P. (2008). Success factors for blended learning. In ASCILITE 2008: Hello! where are you in the landscape of educational technology?: proceedings (pp. 964-968). Deakin University: ASCILITE.

Šumak, B., \& Šorgo, A. (2016). The acceptance and use of interactive whiteboards among teachers: Differences in UTAUT determinants between pre-and post-adopters. Computers in Human Behavior, 64, 602-620.

Sundaravej, T. (2010). Empirical validation of unified theory of acceptance and use of technology model. Journal of Global Information Technology Management, 13(1), 5-27.

Surry, D. W., Ensminger, D. C., \& Jones, M. (2002, April). A model for integrating instructional technology into higher education. In annual meeting of the American Educational Research Association, New Orleans, LA.

Tabor, S. (2007). Narrowing the distance: Implementing a hybrid learning model for information security education. The Quarterly Review of Distance Education, 8(1), 47-57.

Teo, T. S. H., Lim, V. K. G., \& Lai, R. Y. C. (1999). Intrinsic and extrinsic motivation in internet usage. OMEGA: International Journal of Management Science, 27, 25-37.

Thornton, J. (2010). Framing pedagogy, diminishing technology. In H. Song, \& T. Kidd (Eds.), Handbook of research on human performance and instructional technology, (pp. 263-283) IGl global). https://doi.org/10.4018/978-1-60566-782-9.ch016.

Torrisi-Steele, G., \& Drew, S. (2013). The literature landscape of blended learning in higher education: The need for better understanding of academic blended practice. International Journal for Academic Development, 18(4), 371-383.

Tosuntaş, Ş. B., Karadağ, E., \& Orhan, S. (2015). The factors affecting acceptance and use of interactive whiteboard within the scope of FATIH project: A structural equation model based on the unified theory of acceptance and use of technology. Computers \& Education, 81, 169-178.

Tshabala, M., Ndeya-Ndereya, C., \& van der Merwe, T. (2014). Implementing blended learning at a developing university: Obstacles in the way. The Electronic Journal of e-Learning, 12(1), 101-110.

Van der Heijden, H. (2004). User acceptance of hedonic information systems. MIS Quarterly, 28, 695-704.

Vanslambrouck, S., Zhu, C., Lombaerts, K., Philipsen, B., \& Tondeur, J. (2018). Students' motivation and subjective task value of participating in online and blended learning environments. The Internet and Higher Education, 36, 33-40.

Venkatesh, V., Morris, M.G., Davis, G.B. and Davis, F.D., (2003). User acceptance of information technology: Toward a unified view. MIS quarterly, 27(3) pp.425-478.

Wach, H., Broughton, L., \& Powers, S. (2011). Blending in the Bronx: The dimensions of hybrid course development at Bronx community college. Journal of Asynchronous Learning Networks, 15(1), 87-94.

Wang, W. T., \& Wang, C. C. (2009). An empirical study of instructor adoption of web-based learning systems. Computers \& Education, 53(3), 761-774.

Weir, J. P. (2005). Quantifying test-retest reliability using the intraclass correlation coefficient and the SEM. The Journal of Strength \& Conditioning Research, 19(1), 231-240.

Welker, J., \& Berardino, L. (2005). Blended learning: Understanding the middle ground between traditional classroom and fully online instruction. Journal of Educational Technology Systems, 34(1), 33-55.

Zhou, G., \& Xu, J. (2007). Adoption of educational technology ten years after setting strategic goals: A Canadian university case. Australasian Journal of Educational Technology, 23(4), 508-528.

\section{Submit your manuscript to a SpringerOpen ${ }^{\circ}$ journal and benefit from:}

- Convenient online submission

- Rigorous peer review

- Open access: articles freely available online

- High visibility within the field

- Retaining the copyright to your article

Submit your next manuscript at $>$ springeropen.com 